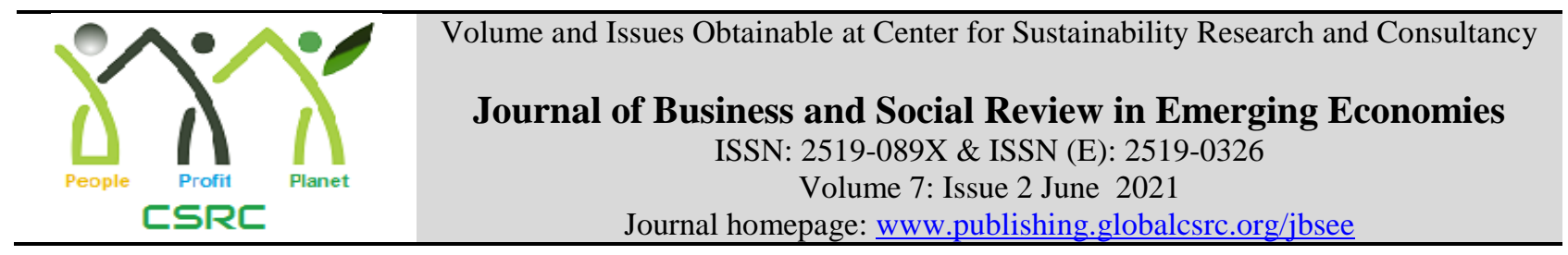

\title{
Jihad, Extremism and Radicalization in Pakistan
}

*Surriya Shahab, Institute of Social and Cultural Studies, Bahauddin Zakariya University, Multan, Pakistan

Muhammad Idrees, Department of Pakistan Studies, Bahauddin Zakariya University, Multan, Pakistan

Shaida Rasool, Department of Pakistan Studies, Bahauddin Zakariya University, Multan, Pakistan

Samana Mehreen, Department of Pakistan Studies, Bahauddin Zakariya University, Multan, Pakistan

*Corresponding author's email: fanibzu@gmail.com

\begin{tabular}{l}
\hline ARTICLE DETAILS \\
\hline History \\
Revised format: : May 2021 \\
Available Online: Jun 2021
\end{tabular}

Keywords

Jihad, Extremism, Militancy, Radicalization in Pakistan, Religion, Radicalization

JEL Classification Z00, Z29

\begin{abstract}
Purpose: The purpose of this study is to fill current information cavities in the present material on the determinants of radicalization. The radicalization has badly affected good governance. Education, health, socio-economic and political system are major components of good governance. This research paper examines the emerging trends of Jihad, Extremism and Radicalization in Pakistan.
\end{abstract}

Design/Methodology/Approach: A survey was conducted a total of 4200 respondents across the country. There was no response from 200 persons and received the response of 4000 respondents, with 2800 people (70 percent) urban and 1200 respondents (30 percent) from rural area. The figure of respondents from each of the four provinces of Pakistan (Khyber Pakhtunkhwa, Punjab, Balochistan, and Sindh, ), Gilgit Baltistan, and Azad Jammu and Kashmir (AJK),entities reveals the percentage of population of each area vis-à-vis the total population of the country.

Findings: The results revealed that the causes of radicalization and extremism are as varied as they are abundant. The study of radicalization, Jihad and extremism in both contexts has sought to find out the causes of radicalization. It is concluded that the root causes of the Islamic militancy and religious radicalization in Pakistan are generally religious, political, ideological, economic, and social in nature.

Implications/Originality/Value: This research paper gives a comprehensive viewpoint and analysis amongst religion, radicalization, governance, extremism, politics, Islamic militancy, sectarianism, conflict and identity. The major root causes of militancy and radicalization were traced out which will be helpful to overcome Islamic militancy, extremism, radicalization and sectarianism in Pakistan. 


\section{OPEN ACCESS}

(C) 2021 The authors, under a Creative Commons Attribution-

NonCommercial 4.0

Recommended citation: Shahab, S., Idrees, M., Rasool, S. and Mehreen, S. (2021). Jihad, Extremism and Radicalization in Pakistan. Journal of Business and Social Review in Emerging Economies, 7 (2), 453-465.

\section{Introduction}

The political geography of Pakistan has been a great source of internal instability. The Punjabi ethnic group has traditionally exerted the most leading influence for the governance of the country as well as over the other ethnic groups in the region, such as the Balochis, Sindhis and Pashtuns, who have histories and linkages to Iran, India and Afghanistan, respectively(Ghosh, 2009). Since its inception, Pakistan became habituated to a country of perpetual crisis, and whiles some of these have a result of circumstances outside the control of the state machinery, most are a consequence of its own action. From its foundation in 1947, Pakistan has remained a state dominated by a powerful military on the one hand, and increasingly authoritative and autonomous insurgent on other. The civilian democratic governments have attempted to function within this construct, but have been repeatedly removed or made redundant by the military when their utility was judged to have ceased. The Extremism and Islamic ethnicity is a great threat to the global harmony and safety and it is also causing the political disturbance and putting a great influence for stable political environment of Pakistan. The Islamic militancy is playing a major role to increase the current wave of radicalization in Pakistan (Basit \&Rathore, 2010). . It has badly affected the governance in Pakistan. The major research on Islamic militancy and extremism is mostly covering the northern areas of Pakistan. There was less focus to study the trends and genesis of radicalization in other parts of Pakistan (Shah, 2020). Radicalization and Islamic Militancy has been a cavernous problematic issue in Pakistan which is causing local and worldwide instability (Shahab, 2010). Radicalization is the practice which is used by the individuals to accept thrilling and dangerous thinking, with views which vehement dealings essential to be drawn for political or religious purposes. It can produce radicalism that is taking on or acceptable of an illogical and thrilling status regarding an issue (Naqi, 2009). According to Safdar Sial and Tanveer Anjum: Religious Radicalization or Islamic Militancy means that Islam is a religion which has a set of views and rehearses that has been seemingly anti-intellectual, antimodern, anti-liberal, and antidemocratic. Thus, as a political ideology, Islamism - also known as Islamic fundamentalism, militant Islam, radical Islam (Sial \&Anjum, 2010).

- generates a mindset that is invariably hostile to non-Muslims, deviant sects, women and liberal Muslims. Ishtiaq Ahmed says that "such a mindset translated into political actions tends to be violence-prone and can give impetus to terrorism (Ahmad, 2009). Similar radicalization, there is no consensus definition and single explanation for radicalization (Azam \& Aftab, 2009). It can be explained in Pakistan in different means, primarily in political, religious, and social contexts(Aftab, 2008). There is lack of consensus of definition of radicalization; it is difficult to accept the real meaning and phenomenon of the radicalization (Rana, 2009). The political marginalization, poverty, economic deprivation and other inequalities, social injustice, sectarian divisions, illiteracy, the role of madrassas and the indoctrination agendas of militant organizations are major root causes of radicalization in Pakistan(International Crisis Group, 2005). The causes of radicalization are as varied as they are abundant. The phenomenon of radicalization in Pakistan can be analyzed in two contexts: one, as part of the larger global phenomenon and exploration of regional and global linkages; and second, as analysis of radicalization's possible connection with religion. The study of radicalization in both contexts has sought to find out the causes of radicalization. 
No doubt, worldwide, it is first time that the Islamists and non-Islamists have been facing same nemesis in the shape of universally affianced Islamist extremism. The current wave of militancy and radicalization has badly affected Pakistan. It totally changed the social structure and political system of Pakistan. Farman Ali says that "the root causes of the Islamic militancy and religious radicalization in Pakistan are generally religious, political, ideological, economic, and social(Ali, 2010)." Charles Kimball highlights that "the genesis of various Islamic radical groups in South Punjab under the umbrella of the religious sectarian factions and their capability to forge close ties to one another is posing a major security threat to global, regional and domestic peace (Kimball, 2001)." The majority of Pakistani believes that Pakistan is an ideological state which was created on the basis of Islam. All India Muslim League made a long struggle for Pakistan on the basis of "Two Nation Theory" and Two Nation Theory was formulated on Islam that Muslim and non-Muslim were two separate nations. Due to creation on ideological basis of Isla, Islam has been a vital character in Pakistan history. Saleem H. Ali says: "While historians differ about the motivation of Pakistan's founder Mohammad Ali Jinnah, regarding the formation of an Islamic state, there is little doubt that contemporary Pakistani identity is anchored in Islam(Ali, 2009)." Abdul Basit and Mujtaba Muhammad Rathore describe that "The Islamic Republican Pakistan has not ever accomplished a separate nationwide identity of its own(Basit \& Rathore, 2010)." Since its existence, Pakistan is facing social and religious clashes between the Westernoriented liberal bureaucracy and a right-leaning clergy. K. K. Aziz says that "the lingering tug-ofwar between a Western-oriented liberal bureaucracy and a right-leaning clergy has further confused the discourse on the national character(Aziz, 2004).". No doubt, majority of Pakistan's citizens have customarily religious identity. The people of Pakistan openly and proudly express to be the followers of Islam. The numbers of researchers think that radicalization and extremism is long-lasting feature of fundamental tendencies in Pakistan and Pakistanis have been divided in to various sects, creed, caste and groups on the basis of religion and social identity. The people's division on the sectarian lines has formed the Pakistani society more complicated. The Muslims in Pakistan have been separated into two major Muslim sects-Shia and Sunni. The Shia sect is further divided into two sub-sects Twelvers and Ismailis. There are four primary Sunni schools of thoughts on the basis of Fiqh: Hanafi, Shafi'i, Maliki and Hanbali. The Hanafi School of Thought is subdivided into Barelvi, and Deobandi. There are Ahl-e-Hadees in Pakistan who don't believe Fiqh. In Pakistan, Twelvers (Shia), Ismailis, Ahl-e-Hadees, Deobandi and Barelvi, have built their separate mosques and Madrassah and they say their prayers and perform their duties according to their sects. Before Soviet invasion into Afghanistan and so-called Afghan Jihad, there was no such sectarian division in rural areas and this wave of sectarianism was grown up after the involvement of Saudis and Iran and USA funding. This division into different sects and castes has more highlighted the religious cleavage.

The main cause for fierce indexes of sectarianism is the presence of several sectarian clutches within different schools of thought who go to gather support for their agendas among the followers of their respective sect. Before so-called Afghan Jihad, Sunni Barelvi Sect followers were more than $75 \%$ of the total population of Pakistan. Shia were 10-12\%, Deobandi were 810\%, Ahl-e-Hadees were 2-3\%. The Barelvi Sect has more mosques and Madrassah. After Afghan Jihad and Iranian Revolution, Deobandi, Ahl-e-Hadees and Shia sects have increased not only their mosques and Madrassah but also more converted Barelvis into Deobandi Sect; Barelvis and Deobandi both belong to Hanafi Fiqh. The Deobandi sectarian organizations are working with different names. The Deobandi sectarian organizations have different wings such as political wing, religious wing, social wing, and militant wing. Tableeghi Jamaat, Sipah-e-Sahaba Pakistan (SSP) Lashar-e-Jhangvi Pakistan Ahl-e- Sunnat Jamaat, and Tehreek-e- Taliban belong to Deobandi Sect. The Deobandi organization has a vast network which is spread almost in whole Pakistan. The militant wings of Deobandi sectarian organizations- Sipah-e-Sahaba Pakistan (SSP), Lashar-e-Jhangvi and Tehreek-e-Taliban are playing most active role and are producing extremism in Pakistan. There have been very few militant wings linked with Ahl-e-Hadees, and 
Shia. Tehreek-e-Labbaik Pakistan and Sunni Tehreek are called the militant wings of the Barelvi organizations but both denied it that they are not militant wings and claim for political parties which are registered before the Election Commission of Pakistan and recent election of 2018 Tehreek-e-Labbaik Pakistan has obtained 2520294 votes. Hassan Abbas says that "the present tendency of extremism in Pakistan has been ascribed to the backing of General Zia's rule to the anti-Soviet 'jihad'(Abbas, 2004).”. The powerful and influenced militant Islamist lobby is working in Pakistan underneath the impact of religious parties. Dr. Muhammad Ishaque Fani says that "a smaller number of violent Sunni and Shia Islamist groups in Pakistan are present who have been influenced by the teaching of Madrassah (Fani, 2007)." Bernard Lewis describes that "the maximum Muslims are not fundamentalists, and most fundamentalists are not terrorists, but most present-day alleged terrorists are Muslims and proudly identify themselves as such (Lewis, 2002)." Ibrahim M. Abu-Rab says that "the Islamists dialogue has got a great deal of consideration globally due to the breakdown of the Soviet Union and the emerging of the New World Oder (Abu-Rabi, 2003)." Majority of the Pakistanis don't believe in extremism and are not radical, and they are lenient, "both of differences within Islam and of non-Muslim believe".

Abdul Basit and Mujtaba Muhammad Rathore describe "although the religious political parties in Pakistan could not get popular support from the people in general elections expect 2002 election, but voters perceptions endorse the need for two things: an increased role of religion in politics, law and society; and the need for social development(Basit \& Rathore, 2010)." From 1947 to till now in general elections, the religious political parties could not succeed and were unable to get majority votes from Pakistani people. The alliance of the religious political parties, Muttahida Majlis-e-Amal (MMA), was succeed to form its provincial government in Khyber Pakhtun Khwa (KPK) in 2002 elections and it was first time in Pakistan history since 1947 that religious parties alliance Muttahida Majlis-e-Amal (MMA) has got 63/342 seats of National Assembly and it had third position in 2002 elections. This victory and performance of Muttahida Majlis-e-Amal (MMA) in the election and the confidence of the voters was considered its success to "the strong anti-American sentiment in the country" (The Friday Times, 200).

During the Zia regime, the role of region was penetrated into Pakistani politics and General Zia has supported and boost up the religious political parties like Jamaat-e-Islami, Jamiat Ulema-eIslam and Jamiat Ulema-e-Pakistan. From last a few decades, religion has been playing an important role and influence in Pakistani politics and it has been happening with active support of Madrassah. The ratio of Madrassah of Deobandi, Shia and Ahl-Hadees is more in South Punjab as compare to other parts of Pakistan. The role of Madrassah cannot be ignored in Pakistani Politics(Shahab, 2010). These Madrassah had played an active role to grow the militant organization in South Punjab and these militant organizations like Lashar-e-Jhangvi (LeJ), Sipahe-Muhammad Pakistan (SMP), Lashkar-e-Tayyabe (LeT), Jaish-e-Muhammad (JeM), Sipah-eSahaba Pakistan (SSP), and Tehrik-e-Jafaria Pakistan (TJP) have strong roots and have a broad base of sympathizers in the population in South Punjab. It is common perception now a days that increase wave of militancy in Pakistan might be connected with a rising number of Madrassah in Southern Punjab. Though, it much complicated and more difficult to analyze the real role of Madrassah and the relationship between the increase numbers of Madrassah and Islamic Militancy in South Punjab but it is clear that Madrassah are involved in terrorist activities. In many cases, they had provided shelters and residences to the terrorist when they launched terrorist acts in South Punjab. During the investigation in many cases, the arrested terrorists confessed that they launched terrorist acts with the help and support of local Madrassah students. Before launching the terrorist acts, they stayed in Madrassah and chalked out the plan. Before the division of united India in 1947, the Bahawalpur State (which is now the part of the South Punjab) has more proportionately and higher number of Madrassa as compare to the other part of Pakistan. Three districts of Bahawalpur division have higher number of Madrasah and this ration is continuously increasing since 1979. The enrollment sheets of Madrassah students and schools 
students were examined and analyzed, it was found out the enrollments of Madrassah students were increasing and en enrollments f Scholl students were continuously decreasing.

In the last two decades, Pakistan had to face experienced of various types of militancy and extremism. The conflicts and nursery of the terrorists are being emerged and in current situation, a new security threat that has emerged in this region is the ever expanding circle of violence by radical Islamist groups. This phenomenon has gained momentum in South Punjab by the influence of Madrassah in developing fundamental visions among the people and particularly in Madrassah students. After 9/11 terrorist attacks on the United States of America, the analysts, researcher and think tanks were more concern to the Madrassah education in Pakistan. Many studies were conducted on Madrassah education in Pakistan and their impact on society. The Number of studies and analysis were views that Madrassah are the nurseries of the terrorism and they are producing many radical and terrorist persons (Shahab, 2010).. Pakistan which has the background of a politically unstable country, less literacy rate region, impoverished by poverty, and disease, conflicts, a foothold by Extremist Islamist groups could further destabilize the region. The manifestation of radical groups in Pakistan including several Al-Qaeda affiliated formations and their associates, such as Al-Qaeda Bare Saghir, Lashkar-e-Jhangvi, Tehreek-eTaliban Pakistan, Jaish-e- Muhammad and other extremist outfits are responsible for extremism and radicalization in Pakistan. These extremist organizations pose a grave threat to the region which is home to almost 220 million people. Some Arab countries and their opponents have become embroiled in Pakistan in a new war waged by these extremist, a conflict that has no front line. The process, pattern and trends of radicalization and extremism are complex phenomena which are mainly attributed to:

- The weakness of the state and governance.

- Poverty and Socio-economic disparities

- Highly illiteracy rate

- Ineffective institutions and lack of welfare service.

- Wrong interpretation of already existing ideologies or the bankruptcy of modern ideologies.

- Most importantly, global nexus of Extremism

- Role of Madaris and Religious Political Parties

- Destabilization of Democratic System

Besides this, psychological factors are also associated with the process of radicalization. A radical Islamic organization can be defined as a group of Muslims having extremist views who want to bring about fundamental change by making the entire world a Kingdom of God. These groups have normally been associated with the Middle East, South Asia and now in many parts of Pakistan. Radical Islam contains various interpretations of the Holy Quran by many people to achieve group or individual objectives. It is commonly promoted through extreme acts of violence and terror as such the recent attacks carried out by Lashkar-e-Jhangvi Lahore.

\section{Literature Review}

The various researches and studies were conducted to find out the root causes of militancy and co-relation of Madrassah education with radicalization. There are a number of literatures available on Madrassah education, Radicalization in Pakistan. The different researchers have identified this issue and problem with different ways. The analysts have studied and analyzed various features, tendencies, outlines, and dynamic of extremism and Islamic militancy in Pakistan in order to know religious ethnicity, extremism and radicalization in Pakistan. Dr. Fani says that: studying the various aspects, trends, patterns, and dynamics of radicalization and sectarianism in Pakistan and their reasons are much complicated in the context of Pakistan, a society that is ethnically heterogeneous and divided along ethno-linguistic, ideological, sectarian and political lines"(Fani, 2007). The available literature on Madrassah education has pointed out 
an important character of Madrassah during the "so-call Afghan Jihad" against the Soviet troops in Afghanistan in 1979 in heat up radicalization in Pakistani society.

In Pakistan, Madrassah network has been spread over the whole country. This network of Madrassah has contributed a lot to increase the existing wave of radicalization in Pakistan. The active part of Madrassah and the brainwashing programs of militant groups are heating up Islamic militancy and sectarianism in Pakistan. It is true that a lot of literature is accessible on Islamic militancy; religious ethnicity and sectarianism in Pakistan; none of the literature is dealing with the matter right way in the local context. The available work on extremism, sectarianism and poor governance in Pakistan has examined and analyzed the phenomenon in the related of the 'jihadi' philosophy laid by Ex.-Army Chief and President General Ziaul Haq's regime in 1977-1988, as well as so called Afghan Jihad. The available literature has found out the root causes of Islamic militancy and sectarianism in Pakistan to the start of ferocious religious separations among the Sunni Deobandi and minority Shia sects. Though in Pakistan Madrassah have been grown up after Soviet Invasion in to Afghanistan in 1979, they could not get the attention of US media and western policy makers before 9/11 terrorist attacks on United States of America.

Jessica Stern describes that "Pakistan' Madaris posed a grave menace, not only to the stability of the South Asian region but also to the US national security interests (Stern, 2001). Her research work is critical encourages this fixation upon Madrassah. Jessica Stern assumed in her study that "Pakistani Madaris are birth place of conceptual indoctrination and armed training for militant groups all through Pakistan and South Asia" (Stern, 2000). Peter Singer and Robert Looney also have taken up the matter of Madrassah education and pointed out that "there are clear links between the Madaris and militants" (Singer, 2001). (Looney, 2002). They have argued that in Pakistan majority of the militant is Madaris students and many Madaris are performing as facilitators for the militants. The International Crises Group (ICG) has submitted a research a report in 2002 that indicated "the threats and dangers which are posed by the Madaris in Pakistan" (ICG, 2002).. The report alleged that the public schools and private schools are totally failed to provide space for students to get education in rural areas and about a third of all students in Pakistan were enrolled in the Madaris. It is very important fact and matter was more significance that the Director of ICG in Pakistan, Samina Ahmad, "who prepared the report was directed to appear before the Senate Foreign Affairs Committee in April 2005 and present report about the links between Madaris and terrorism" (Lugar, 2005). Since 2001, an alternative opinion of the Islamic militancy, and religious ethnicity was given in various research articles and editorials in different newspapers at local level and internationally. There is a lot of research work and studies were carried out on "Ziaul Haq's Islamization programs and the Islamic Jihad Culture which was sponsored during the Soviet invasion in to Afghanistan. This literature describes that Afghan war is liable for the development of religious extremism in Pakistan. Oliver Roy has studied "the growth of religious extremism and the 'jihad' culture in the backdrop of the anti-Soviet jihad" (Roy, 2002).

Ayesha Jalal has given her findings in her book that "challenges reductive understandings of jihad as holy war against non-Muslim infidels by providing a rich intellectual history of the shifting, diverse, and contested meanings of jihad in South Asia: (Jalal, 2008). Amir Mir's the Fluttering of Jihad states that while the Bush era is coming to a fag end amidst an endless war on terror, the Taliban-style militias are again spreading out rapidly from the Pakistan and Afghanistan border provinces and Federally Administrated Tribal Areas(FATA) which are much different today to the Taliban-controlled Afghanistan before the 9/11 attacks (Mir, 2008). C. Christine Fair has carried out her study "Islamic Militancy in Pakistan: A View from the Provinces" empirically and examined the people's views and beliefs regarding the Islamic militancy, extremism and sectarianism. She also evaluated the beliefs of the Pakistani government and discussed response of the government to the Islamic militancy and religious 
ethnicity and sectarianism (Fair, 2005). Muhammad Qasim Zaman examines the pattern and trend of radicalization of Shia and Sunni in the backdrop of the Iranian Revolution 1979, implementation of Zakat Ushr Zakat Ordinance 1979 in Pakistan and resultant awakening of the Shia sect(Zaman, 1998). Rana Muhammad Amir has examined the root causes that drive people to become a 'jihadi'. The author then details the multi-faceted organizations that mix religion with politics, as well as questioning the role of the Western world in creating problems(Amir, 2003)..Rana Muhammad Amir and Rohan Gunaratna have discussed different trends and pattern of terrorism in Pakistan and analyzed the role of Al-Qaeda in the Pakistan(Amir \& Gunaratna, 2007). Aqeel Yousafzai highlighted that "the Taliban cross border movements from Afghanistan to Pakistan and from Pakistan to Afghanistan has become the most complicated matter among Pakistan and Afghanistan relations. The attacks were carried out by Taliban against the US-led forces, Afghan government, NATO and ISAF in Afghanistan and in the Tribal Areas and Swat District of Pakistan". (Yousafzai, 2009). "The growth of Islamic militancy, religious ethnicity and sectarianism in Pakistan has been examined by Hassan Abbas particularly since 1947, and has been evaluated its links to the Pakistani army's corporate interests and U.S.-Pakistan relations(Abbas, 2004). The Washington DC based Middle East Institute, has issued a report titled "the Islamization of Pakistan, 1979-2009" which explains "the history of extremism, Islamic militancy and radicalization in Pakistan in the context of the Iranian Revolution" (The Middle East Institute, 2011). The Asia 2005 report issued by International Crisis Group in 2005 was a useful and helpful peace of work to study and analyze the links between Islamic militancy, extremism and the tendencies of radicalization in Pakistan"(International Crisis Group, 2005)..Raheem ul Haqu has examined the "Youth Radicalization in Pakistan" and submitted a report which has been published by United States Institute of Peace, Washington, D.C. on February 26, 2014. Raheem ul Haqu has explained the procedure of youth radicalization in Pakistan and has recommended "how the governmental institution and policy makers can best confront the growing challenge". He further explained that "Pakistan has faced serious challenges and threats of terrorism, extremism, radicalization and Islamic Militancy; and more than 47,000 thousands lives have been lost in terrorism-related violence in Pakistan over the past decade" (Haque, 2014).He gave his recommendations that "opposing youth radicalization in Pakistan needs an all-inclusive approach that helps political, social and educational alternatives to exclusionary Islamic Identities, reducing the space for groups that espouse violence in the name of an exclusive Islamic Identity". Danial Wagner in his article points out that the main reason for Islamic radicalization d States in Asia is the ungovernable states, what he calls 'the Asian Confederation of failed states'. Due to these failed states Muslim radicalization has reached on its peak as these states have no check on the activities of extremists due to their poor governance, corruption and resource scarcity (Wagner, 2017). Charlie Warren says that when Robert Kaplan indicated that extremism is making its strongholds in Asia, nobody gave attention to that. Now the 'Coming Anarchy' has reached in the region of West Africa making it a home to several radical organizations as Boko Haram, Al-Qaeda in the Islamic Maghreb etc. Charlie Warren also indicates that the recent rise of terrorism has its basis in insatiable political condition of the region, local grievances, the illicit flow of weapons and money and the crass border infiltration(Warren, 2012). Tatah Mentan describes the overall security challenges of Africa whether conventional or non-conventional. He examines in detail the political, social and, economic insecurities prevailing in the region and lays emphasize on how to get rid of these diverse challenges(Menton, 2014).. Zachary Devlin-Foltz says that Africa's fragile and failed states are crafting such political and security situations which are increasing the leverage of Islamist fanatics in their continuing fight with moderates for influence. He indicates that counterextremism and counter-terrorism approaches in Africa cannot be disjointed from building stronger, more legitimate states (Foltz, 2010). Fatwas was examined in detailed by Shmuel Bar and he explained that "Fatwas are legal views proclaiming whether a given act under Islam is compulsory, permitted or not allowed, which works as a main device by which religious leaders coerce justify believers to engage in acts of Jihad". Shmuel Bar describes that "Islamic 
jurisprudence performs an important role in determining for believers the practical meaning of the duty to jihad". He has discussed "the extensive scope of matters that these fatwas deal with, covering almost all facets of Islamic law of war: the rationalization for declaring jihad; the land in which the jihad should be fought; whether women and children may participate in jihad; the legality of killing women, children and other non-combatants". He has "elevated different questions relating to the Religious Policy of the West in the face of the threat of Islamic extremism" (Shmuel, 2006). Robert Rothberg has examined the detailed situation of terrorism in African Region and described that" the eliminating both of present extremist and guerilla cells and possible forthcoming terrorist threats and combinations cannot be achieved without careful, considered attention to uplifting governance in general throughout the region of Africa". Robert Rothberg has explained that "nearly all of the nations are fighting against terrorism with the help of United States of America or without her help and the United States of America can and will help the region upgrade its counterterror and security operations, especially a harbors and airports, but its more profound task is to help inoculate the ground against the spread of terrorist sympathizers". He says that "means winning hearts and minds, which-for victory in the ultimate combat against Al Qaeda and terrorism-means helping to strengthen governance and improve the life prospects of all of the inhabitants of this crucial and endangered region" (Rotberg, 2005). Robert Rothberg has described that "the ways through which terrorism has reached on its peak in the region". The Washington, D.C. based the International Republican Institute (IRI) has conducted a survey in Pakistan in 2009 and collected public responses from Pakistani people on Pakistan's coalition with the United States of America against war on terror and in the survey Pakistani people were questioned and asked to give their views about Al-Qaeda, Tehreek-eTaliban Pakistan(TTP), Afghan Taliban, and Jaish-e-Muhammad (JeM), Lashar-e-Jhangvi (LeJ), Sipah-e-Muhammad Pakistan (SMP), and Punjabi Taliban in Pakistan(Ramsey, Kull, Weber, \& Lewis, 2009). The joint public opinion survey of urban Pakistanis on a wide array of compelling policy questions on Democracy, Islamist Militancy, and Relations with the United State of America was conducted by C. Christine Fair; Clay Ramsay; and Steve Kull from September 1218, 2007 under the umbrella of United States Institute of Peace (USIP), Washington, D.C. and World Public Opinion organization. The 907 adults urban Pakistanis have participated in the survey. The multi-stage probability sampling method of 907 Pakistan urban adults was used. The interviews were conducted from the 19 cities of Pakistan. The participants were asked to explore their views on the role of Islam, democracy, militant groups in Pakistan, and relations between Pakistan and United States of America. "The study lacked a homogenous sample representative of entire Pakistani populations and public perspectives on social, cultural and ideological fronts" (Fair, Ramsay, \& Kull, 2008).

Sabeeha Hafeez has worked on The Changing Pakistani society and described that "Any attempt to Islamize the social sciences is very likely to engender fanaticism, emotionalism, and post-facto analysis on or interpretation of social realities" (Hafeez, 1991). Dr. Muhammad Ishaque Fani has described that "the literature review has provided and informed a detailed conceptual framework which has defined key concepts under study, and the hypothesized relationships that were being tested" (Fani, 2007).

\section{Hypothesis}

Pakistan is the flash point of Jihad, Extremism and Radicalization which is causing instability in Pakistan.

\section{Significance and Utility of the Research Work}

This research paper gives a comprehensive viewpoint and analysis amongst religion, radicalization, governance, extremism, politics, Islamic militancy, sectarianism, conflict and identity. The major root causes of militancy and radicalization were traced out which will be helpful to overcome Islamic militancy, extremism, radicalization and sectarianism in Pakistan. 
The finding and recommendation of the study will be utilized to eliminate radicalization, Islamic Militancy in Pakistan. The Think Tanks Experts, Researchers, Educationists, and Policy Makers will get benefit from this research and will use the findings and recommendations for their wider purposes.

\section{Scope and Objectives of the Study}

The aim of this study is to fill current information cavities in the present material on the determinants of radicalization. The radicalization has badly affected good governance. Education, health, socio-economic and political system are major components of good governance. If there is socio- economic and political instability, the governance will be das and ineffective.

\section{Research Methodology}

Wanda Thomson Bernard describes that "research is the creation of information regarding a given substance matter and researcher who create and regulate information rise up their power to deal with the particular Issues involved" (Bernard, 2000). In other words, Sushil R. Pandey says that "The methodology is the order line of any research work, which deals with the technique of investigation of phenomena and process of research, essentially empirical in data collection and data analysis" (Pandey, 2001). The current research deals with the questions, trends and genesis of radicalization in South Punjab and its impact on governance. The current wave of militancy in South Punjab has been badly affecting the good governance. The bad and poor governance has enhanced the militancy in South Punjab. The poor performance of governmental Institution has failed to combat terrorism in South Punjab. The research work was conducted to use primary and secondary data.

The experimental and quasi-experimental research design had been used to conduct and complete this research work. For this purpose sample frame and sampling methodology of purposive, simple random, systematic random sampling was used. For conducting this research work, regression analysis had been used. The available material, data and literature on the purposed topic was carefully and systematically was examined and used. The interviews and survey were conducted from the general public, School, college, university and Madrassah students, and policy makers and those who are involved in governance related activities, either formally or informally. The public materials already collected by various government and semigovernment/autonomous bodies, ware also examined and utilized for the research. I have also gone through the individual's research reports, findings of think tanks, articles, newspapers, magazines, books to complete my research work. I have conducted this research work by using the theoretical as well as applied methodology. For the study of context of historical perspective and analysis, Hedley Bull has strappingly "encouraged and recommended a research agenda for the study of world politics based on historical methodology as opposed to a total reliance on a scientific approach derived from behavioral methods" (Bull, 1972). This method was also adopted to complete this research. Dorothy W. Baruch describes that the use of history enables the scholars to understand the particular characteristics of a state (Baruch, 1952). (Banfield, 1961).

\section{Field Survey}

Field survey is a quantitative research technique and methods to use widely basis on variety of data-collecting, along with different types of interviews, questionnaires, tape recordings., $\mathrm{C}$. Wright Mills says that "quantitative techniques and content analysis of essays and stories are used in empirical research" (Mills, 1951). Fink describes "surveys as ways of producing information to describe, compare and predict attitude, opinion, values and behavior based on what people say or see and what is contained in records about them and their activities" (Fink, 1995).. Ackroyed and Hughes characterize "survey into four distinct categories: factual; attitudinal; social psychological and explanatory" (Ackroyed \& Hughes, 1993). Gans' research of 
"Levittown was based on questionnaires, interviews and participant observation" (Gans, 2017). Karsh in his study of "strike used structural interviews that were subjected to content analysis and also files correspondence, photographs, newspapers clipping, songs, and court transcripts, outlines of speeches, notes and personal memos" (Karsh, 1958). During this research, a field survey had been conducted to get data for analyzing the trends, patterns, dynamics and dimensions of radicalization in South Punjab. The date had been collected through a random survey and common questionnaires, in-depth person's interviews.

Matt Stroh says that "the Usage of interviews in various research projects is now wide-spread and widely accepted. These offer the opportunity to sit and listen to people's concerns and onions at a level in accessible to a questionnaire" (Stroth, 2000). Interviews are used extensively by sociologists that Benny and Hughes have referred to Modern Sociology as "the Science of the Interview" (Burgess, 1995). According to Dawn Burton, "Face-to-face interviews are better at eliciting data to open-ended questions and self-administrated questionnaires are better generating information from highly structured questions where respondents are required to tick an appropriate box" (Burton, 2000).

A survey was conducted a total of 4200 respondents across the country. There was no response from 200 persons and received the response of 4000 respondents, with 2800 people (70 percent) urban and 1200 respondents (30 percent) from rural area. The figure of respondents from each of the four provinces of Pakistan (Khyber Pakhtunkhwa, Punjab, Balochistan, and Sindh, ), Gilgit Baltistan, and Azad Jammu and Kashmir (AJK), entities reveals the percentage of population of each area vis-à-vis the total population of the country. The 1008 persons (36 \%) of the participants had been from urban Punjab; 432 participants $(36 \%)$ of the respondents were from rural Punjab; 448 participants (16\%) of the respondents were from urban Sindh; 192 persons (16 percent) of the respondents were from rural Sindh; 672 persons ( 24 percent) of the respondents were from urban Khyber Pakhtunkhwa; 288 persons (24 percent) of the respondents were from rural Khyber Pakhtunkhwa; 280 persons (10 percent) of the respondents were from urban Balochistan; 120 persons (10 percent) of the respondents were from rural Balochistan, 140 persons ( 5 percent) of the respondents were from urban Azad Jammu Kashmir (AJK); 60 persons (5 percent) of the respondents were from rural Azad Jammu Kashmir (AJK); 168 persons (6 percent) of the respondents were from urban Gilgit Baltistan, 72 persons (6 percent) of the respondents were from rural Gilgit Baltistan; 84 persons ( 3 percent) of the respondents were from urban area of federal capital Islamabad and 36 persons ( 3 percent) of the respondents were from rural area of federal capital Islamabad. An effort was also made to ensure representation of respondents from different age groups, literacy levels and status of employment. 1640 respondents(41 percent) were from the 16-20 year age group, 1400 respondents(35 percent) were between 20-25 years, 320 respondents ( 8 percent) were from 25-30; 240 respondents( 6 percent) were between $30-40 ; 400$ respondents(10 percent) were 40 or above. The 240 respondents $(6 \%)$ were M. Phil Degree holders, 320(8\%) were Master's Degree, 1400 respondents(35\%) were Graduate Degree holders, 1520(38\%) were intermediate. Barely 400(10\%) of the people were illiterate and $120(3 \%)$ had only received Madrassah education. On the social status, most of the respondents were not very wealthy: only 1000 respondents $(25 \%)$ had their own vehicles, 400 people $(10 \%)$ used private vehicles while 2600 persons $(65 \%)$ relied on public transportation. 840 persons (21\%) were students who were without jobs, 2680 persons (67\%) belonged to the salaried class as $1680(42 \%)$ were employed in public sectors and $1000(25 \%)$ were in private sectors - while only 480 persons (12 per cent) ran their own business. The composed material and statistics and facts had been examined and scrutinized. This analysis was useful and helped to know the ground realisms of the Radicalization in Pakistan particularly in South Punjab. 


\section{Conclusion}

Radicalization and Islamic Militancy has been a cavernous problematic issue in Pakistan which is causing local and worldwide instability. Radicalization is the practice which is used by the individuals to accept thrilling and dangerous thinking, with views which vehement dealings essential to be drawn for political or religious purposes. The political marginalization, poverty, economic deprivation and other inequalities, social injustice, sectarian divisions, illiteracy, the role of madrassas and the indoctrination agendas of militant organizations are major root causes of radicalization in Pakistan. The causes of radicalization and extremism are as varied as they are abundant. The phenomenon of radicalization in Pakistan can be analyzed in two contexts: one, as part of the larger global phenomenon and exploration of regional and global linkages; and second, as analysis of radicalization's possible connection with religion. The study of radicalization in both contexts has sought to find out the causes of radicalization. The current wave of militancy and radicalization has badly affected Pakistan. It totally changed the social structure and political system of Pakistan. It is concluded that the root causes of the Islamic militancy and religious radicalization in Pakistan are generally religious, political, ideological, economic, and social in nature. No doubt, majority of Pakistan's citizens have customarily religious identity. The people of Pakistan openly and proudly express to be the followers of Islam. The numbers of researchers think that radicalization and extremism is long-lasting feature of fundamental tendencies in Pakistan and Pakistanis have been divided in to various sects, creed, caste and groups on the basis of religion and social identity. The people's division on the sectarian lines has formed the Pakistani society more complicated. The Muslims in Pakistan have been separated into two major Muslim sects-Shia and Sunni. The Shia sect is further divided into two sub-sects Twelvers and Ismailis. There are four primary Sunni schools of thoughts on the basis of Fiqh: Hanafi, Shafi'i, Maliki and Hanbali. The Hanafi School of Thought is subdivided into Barelvi, and Deobandi. There are Ahl-e-Hadees in Pakistan who don't believe Fiqh. In Pakistan, Twelvers (Shia), Ismailis, Ahl-e-Hadees, Deobandi and Barelvi, have built their separate mosques and Madrassah and they say their prayers and perform their duties according to their sects. Before Soviet invasion into Afghanistan and so-called Afghan Jihad, there was no such sectarian division in rural areas and this wave of sectarianism was grown up after the involvement of Saudis and Iran and USA funding. Before Soviet invasion into Afghanistan and so-called Afghan Jihad, there was no such sectarian division in rural areas and this wave of sectarianism was grown up after the involvement of Saudis and Iran and USA funding. This division into different sects and castes has more highlighted the religious cleavage. The main cause for fierce indexes of sectarianism is the presence of several sectarian clutches within different schools of thought who go to gather support for their agendas among the followers of their respective sect. Before so-called Afghan Jihad, Sunni Barelvi Sect followers were more than $75 \%$ of the total population of Pakistan. Shia were 10-12\%, Deobandi were 810\%, Ahl-e-Hadees were 2-3\%. The Barelvi Sect has more mosques and Madrassah. After Afghan Jihad and Iranian Revolution, Deobandi, Ahl-e-Hadees and Shia sects have increased not only their mosques and Madrassah but also more converted Barelvis into Deobandi Sect.

\section{References}

Abbas, H. (2004). Pakistan's Drift into Extremism: Allah, then Army, and America's War Terror. Routledge Publications.

Abdul Basit, A. \& Rathore. (2010). Trends and Patterns of Radicalization in Pakistan. Conflict and Peace Studies, A PIPS Research Journal, 3(2), 19-30.

Abu-Rabi, I.( (Ed.).(2003). Islam at the Cross Roads: On the Life and Thought of Bedi-Uzzaman Said Nursi, Albany. State University of New York Press.

Ackroyed, S. \& Hughes, J.(1993). Data Collection in Context. Longman Publications.

Aftab, S. (2008). Poverty and Militancy, Conflict and Peace Studies, 1(1), 65-86;

Ahmed, I. (2009). Radicalization and De-Radicalization in Singapore and Pakistan: A Comparison, Conflict and Peace Studies, 2(3), 40-55. 
Ali, F.(2010). The Rise of Militant Islam in Pakistan: Its Impacts on Society [Unpublished M. Phil Thesis]. Bahauddin Zakariya University.

Ali, S. (2009). Islam and Education. Oxford University Press.

Amir, R. \& Gunaratna, R.(2007). Al Qaeda Fights Back inside Pakistani Tribal Areas. e: Pak Institute for Peace Studies.

Amir, R.(2003). Gateway to Terrorism. Gardners Books..

Azam, M. \& Aftab, S.(2009). Inequality and the Militant Threat in Pakistan, Conflict and Peace Studies, 2( 2), 33-46.

Aziz, K.K.(2004). The Murder of History in Pakistan. Vanguard Publishers.

Banfield, E.(1961). Political Influence. Free Press.

Baruch, D. (1952). One Little Boy. Julian Press.

Basit, A., \& Rathore, M. (2010). Trends and Patterns of Radicalization in Pakistan, Conflict and Peace Studies, A PIPS Research Journal, 3(2), 10-32.

Bernard, W. (2000). Participatory Research as Emancipatory method: Challenges and Opportunities, in Dawn Button (Ed.), Research Training for Social Scientists. Sage Publications, 160-178.

Bull, H. (1972). International Relations as an Academic Pursuit, Australian Outlook, 26, 251262.

Burgess, R. (1995). In the Field: An Introduction to Field Research. Rutledge Publisher.

Burton, D. (2000). Data Collection Issues in Survey Research. In Dawn Burton (Ed.), Research Training for Social Scientists. Sage Publications.

Charles Kimball, C. (2001, October 24). Roots of rancor: Examining Islamic militancy. The Christian Century Magazine, Michigan, pp.10-45.

Charlie Warren, C.(2012). Terrorism in West Africa: The Anarchy That Hasn't Come, Security Watch, 3(2), 34-45.

Christine Fair, C., Ramsay, C., \& Kull, S.(2008). Pakistani Public Opinion on Democracy, Islamist Militancy, and Relations with the US., United States Institute of Peace (USIP) and World Public Opinion organization.

Fair, C.(2005). Islamic Militancy in Pakistan: A View from the Provinces, Modern Asia Studies,32(3), 620-630.

Fani, M.(2007). Islamic Militancy, Religious Ethnicity; Causes and Roots: Its Impacts on Society, A Case Study of Pakistan[Unpublished Post-Doctoral Research Work].University of Pennsylvania.

Fink, A. (1995). How to Design Surveys. Sage Publications.

Foltz, D. (2010). Africa's Fragile States: Empower in Extremists, Exporting Terrorism, Africa Security Brief, 6, 1-8.

Gans, H. (2017). The Levit Towner's: Ways of Life and Politics in a New Suburban Community. Columbia University Press.

Ghosh, S. (2009). Pakistan and Terrorism. In Maroof Raza (Ed.), Confronting Terrorism (pp.110-135). Penguin Group.

Hafeez, S. (1991). The Changing Pakistani society. Royal Book Company.

Haque, R.(2014). Youth Radicalization in Pakistan. United States Institute of Peace.. https://www.usip.org/publications/2014/02/youth-radicalization-pakistan.

International Crisis Group (2005). , The State of Sectarianism in Pakistan, in Asia Report 2005, http://www.crisisgroup. org/home/index.cfm?id=3374\&1=1.

International Crisis Group (ICG). (2002). Pakistan: Madrasas, Extremism and the Military. Asia Report No. 36. Retrieved from: http://merln.ndu.edu/ archive/icg/pakistanmadrassasextremismandthemilitary.pdf).

International Crisis Group.(2005). The State of Sectarianism in Pakistan. http://www.crisisgroup. org/home/index.cfm?

Jalal, A.(2008), Partisans of Allah: Jihad in South Asia. Harvard University Press.

Karsh, B.(1958). Dairy of a Strike, University of Illinois Press. 
Lewis, B.(2002). The Crises of Islam: Holy War and unholy Terror. Orion House Publishing. Looney, R.(2002). A U.S. Strategy for Achieving Stability in Pakistan: Expending Educational Opportunities Strategic Insights. The Center for Contemporary Conflicts, U.S. Naval Postgraduate School.

Lugar, R.(2005). Combating Terrorism through Education: The Near East and South Asian Experience. Full Committee Hearing, Washington. D.C.: United States Senate Committee on Foreign Relations. https://www.foreign.senate.gov/hearings/combating-terrorismthrough-education-the-near-east-and-south-asian-experience.

Menton, T.(2014). Africa: Facing Human Security Challenges in the 21st Century. African Books Collective.

Mills, C. (1951). White Collar. Oxford University Press.

Mir, A.(2008). The Fluttering Flag of Jihad, Mashal Books.

Naqi, H. (2009). Defining the Phenomenon of Radicalization in Pakistan, Conflict and Peace Studies, 2(1), 10-25.

Pandey, S.(2001). Methodology in Social Sciences Research. Nepal Centre for Contemporary Studies.

Ramsey, C., Kull, S., Weber, S.,\& Lewis, E.(2009). Pakistani Public Opinion on the Swat Conflict, Afghanistan, and the US. http://www.worldpublicopinion.org/pipa/pdf/jul09/WPO_Pakistan_Jul09_rpt.pdf

Rana, A. (2009). Mapping the Madrassa Mindset: Political Attitudes of Pakistani Madaaris, Conflict and Peace Studies, 2(2), 27-42.

Rotberg, R.(Ed.).(2005). Battling Terrorism in the Horn of Africa. Brooking Institute Press.

Roy, O.(2002). Islamic Radicalism in Afghanistan and Pakistan. WRITENET Paper No. 06/2001, UNHCR.

Shah, N. (2020). Saraiki Region: Roots of Radicalization. Takleeqat Publisher.

Shahab, S. (2010). The Challenges of Religious Radicalization and Militancy in Pakistan and Strategies for countering their effect: A case Study of Southern Punjab Madaris and Mosques [Unpublished M.Phil. Thesis]. Bahauddin Zakariya University.

Shmuel, B.(2006). Warrant for Terror: The Fatwas of Radical Islam and the Duty to Jihad. Rowman \& Littlefield Publishers.

Sial, S. \& Anjum, T.(2010). Jihad, Extremism and Radicalization: A Public Perspective, Conflict and Peace Studies, A PIPS Research Journal, 3(2), 30-40.

Singer, P.(2001).Pakistan's Madrassah's: Ensuring a System of Education, Not jihad.

Washington D.C.: The Brookings Institute, Analysis Paper No. 14.

(www.brookings.edu/views/papers/singer/20020103.pdf).

Stern, J(200). Pakistan's Jihad Culture, Foreign Affairs.

Stern, J.(2001). Meeting with the Muj.(Pakistan-Islamic Fundamentalist School), Bulletin of the Atomic Scientists, 57(1), 42-51.

Stroh, M. (2000). Qualitative Interviewing. In Dawn Burton (Ed.), Research Training for Social Scientists (pp. 213-214). Sage Publications.

The buck stops at General Musharraf.(2002, October 18-24). The Friday Times (Weekly.

The Middle East Institute (2011). Islamization of Pakistan, 1979-2009. Washington DC:

Wagner, D. (2017).Virtual Terror: 21st Century Cyber Warfare, Create Space Independent Publishing Platform.

Yousafzai, A.(2009). Talibanization: Afghanistan se FATA, Swat Aur Pakistan tak(Urdu), Negarashat Publishers.

Zaman, Q.(1998).Radicalization of Shi'i and Sunni Identities, Modern Asia Studies, 32(3), 689716. 